\title{
„Lektura nieporządku”: kilka przykładów narracji autobiograficznych z okresu Zagłady
}

DOl: 10.19195/2083-7763.7.5

\section{Opisywanie Zagłady}

W badaniach nad narracjami osobistymi podkreśla się, że służą one ustrukturalizowaniu własnych doświadczeń, są próbą znalezienia i ukazania porządku w życiu autora oraz otaczającym go świecie. W przypadku dokumentów osobistych z okresu Zagłady u części narratorów widać tendencję przeciwną, mianowicie dążenie do ukazania katastrofy, zerwania ciągłości dziejów, własnego zagubienia w zmieniającej się rzeczywistości. Jednak, jak twierdzi James E. Young, opisując własne doświadczanie przemocy, włączając je w porządek narracji, autorzy odbierają mu status nieprzyswajalnego poznawczo i wpisują je w continnum dziejów ${ }^{1}$.

Dlatego warto przyjrzeć się próbom zapisania i zrozumienia katastrofy, chaosu, rozpadu świata. Zostawiam na marginesie uwagi cały nurt refleksji nad wyrażalnością doświadczenia Zagłady. W kilku przykładach narracji osobistych, powstałych zarówno hic et nunc, jak i już ex post- po wojnie, interesuje mnie sposób przedstawienia doświadczenia ekstremalnego. Wybrane przykłady literatury dokumentu osobistego pochodzą z terenu Polski, przede wszystkim z Warszawy. Ich autorkami były młode kobiety, właściwie dziewczęta, ale już nie dzieci — w $1939 \mathrm{r}$. uczennice szkół średnich. Ich zapiski to świadectwa tak zwanych zwykłych ludzi ${ }^{2}$,

1 J.E. Young, Interpreting Literary Testimony: a Preface to Rereading Holocaust Diaries and Memoirs, „New Literary History” 18, 1987, nr 2, s. 404.

2 Odwołuję sie do rozumienia kategorii „zwykłych ludzi” („kleine Leute”) według A. Lüdtke (The History of Everyday Life: Reconstructing Historical Experiences and Ways of Life, Princeton 1995). 
pozostających na marginesie tradycyjnej narracji historycznej i na ogół nie zostawiających po sobie świadectw pisanych.

Obie wojny światowe jako wielkie konflikty XX wieku przyniosły ogromną liczbę świadectw zostawionych właśnie przez zwykłych ludzi - wcześniej anonimowych, „nieważnych” aktorów historii, teraz pragnących udokumentować cierpienia własne, swoich bliskich, rodaków. Ich indywidualne przeżycia i doświadczenia mają rangę momentu historycznego i, jak dalej twierdzi Arlette Farge, historia powinna zajmować się właśnie sprawami partykularnymi, odczuciami i emocjami ${ }^{3}$. Paul Ricoeur zakłada, że ostatecznym przedmiotem badania historycznego są ludzie tacy jak my, działający i cierpiący, uzależnieni w różny sposób od okoliczności zewnętrznych ${ }^{4}$. Zasługują na zainteresowanie w swojej jednostkowości, nie tylko jako przedstawiciele formalnych, czy też nie, grup społecznych.

$\mathrm{Z}$ punktu widzenia nowej historiografii, czerpiącej między innymi z inspiracji mikrohistorycznych, zapis doświadczenia indywidualnego mówi o doświadczeniu zbiorowości. Jest albo wyjątkiem, albo potwierdzeniem reguły; dowodzi zakłóceń lub sprawności funkcjonowania mechanizmów regulujących życie społeczne. Projekt historii widzianej „od dołu”, z perspektywy jej „nieważnych”, anonimowych aktorów, pozwala uchwycić szersze zjawiska przez indywidualne intencje, strategie postępowania i wybory osób, które się z nimi zetknęły.

Tak zwani zwykli ludzie rzadko jednak zostawiają zapiski. Pisanie o sobie poniekąd wyłącza z kategorii zwyczajności. Wyjątkiem są nadzwyczajne okoliczności, takie jak wojna. Zburzenie bezpiecznej rutyny dnia codziennego, lęk, cierpienie sprawiają, że własna egzystencja nabiera ważności, staje się godna opowiedzenia. W istocie, jak zaznacza Farge, zapisana historia, czy to życia publicznego, czy prywatnego, zbudowana jest wokół wydarzeń zaburzających harmonię, niszczących porządek, zakłócających „naturalny” bieg rzeczy, prowokujących cierpienie ${ }^{5}$. Częściej i wyraźniej o historii mówią zapisy przerwania ciągłości „normalnej” ludzkiej aktywności, zapisy cierpienia. A cierpienie, osobiste poczucie nieszczęścia stanowią częsty impuls pisarstwa autobiograficznego ${ }^{6}$. Jak podkreśla Jerome Bruner, tworzenie narracji związane jest ze świadomością łamania konwencji społecznych, a to zawsze jest, mniej lub bardziej, boleśnie odczuwa$n^{7}$. Odtworzenie sposobów przeżywania i wyrażania cierpienia daje nie tylko

3 A. Farge, Des lieux pour l'histoire, Paris 1997, s. 25-26.

4 P. Ricoeur, Histoire et rhétorique, „Diogène” 1994, nr 168, s. 9-26.

5 A. Farge, op. cit., s. 16.

${ }^{6}$ A. Giza-Poleszczuk, Życie jako opowieść: analiza materiałów autobiograficznych w perspektywie socjologii wiedzy, Wrocław 1991, s. 115; Giza-Poleszczuk formułuje banalną, ale trafną obserwacje, iż zapiski autobiograficzne prowadzą przede wszystkim ludzie nieszczęśliwi. Krzywda, nieszczęście stają się tym, o czym warto, i trzeba, pisać.

7 J. Bruner, The Narrative Construction of Reality, „Critical Inquiry” 1991, nr 18, s. 15. 
możliwość wniknięcia w przeszłość, lecz także wytwarza dyspozycję pozwalającą zrozumieć teraźniejszość społeczności ${ }^{8}$.

Literatura dokumentu osobistego jest specyficznym, przez tradycyjną historiografię niezbyt cenionym, źródłem. To przekaz z założenia subiektywny, albowiem kategorią ponadgatunkową wyróżniającą obszar pisarstwa osobistego jest postawa autobiograficzna ${ }^{9}$. Dla historii ludzkiego doświadczenia nie jest to wadą. Wręcz przeciwnie, cenna jest indywidualna opowieść, która przedstawia, kim jest człowiek i w jaki sposób doświadcza świat. Pisarstwo osobiste przedstawia bowiem życie opisane, zinterpretowane przez autora narracji, a zatem zapis, przedstawienie jego doświadczeń. Reguły narracji stają się sposobem nie tylko opisywania świata, ale i jego rozumienia ${ }^{10}$. Budują "tożsamość narracyjną" autora ${ }^{11}$.

Ponieważ „,historia jako obraz przeszłych wydarzeń nie jest prostym odwzorowaniem tego, co było, lecz stanowi pewną konstrukcję narracyjną, przedmiot zorganizowanej według przyjętych zasad opowieści”, ważne jest, jaką strategię pisania o swoim życiu przyjmie autor ${ }^{12}$. Czy będzie to relacja z pozycji świadka, w sposób epicki opowiadająca o ludziach i wydarzeniach, skoncentrowana na świecie opisywanym, czy też postawa wyznania, skupiająca się na życiu osobistym jednostki ${ }^{13}$. Odsłonięcie strategii pisania jest sprawą podstawową. Opowiadanie o własnych przeżyciach warunkowane jest bowiem nie tylko autorefleksją podmiotu, lecz także wyborem określonej konstrukcji narracyjnej ${ }^{14}$. To ona mówi, jaki projekt rozumienia świata i siebie samego przyjmuje autor. Przez nią opowieść jest zapisem jednostkowego wydarzenia historycznego - indywidualnej historii życia.

Indywidualna historia życia zyskuje na atrakcyjności, gdy rozgrywa się w nadzwyczajnych okolicznościach. Inaczej, dla samego jej podmiotu, wydawać się może zwyczajna, przeciętna, niezasługująca na uwagę nikogo spoza wąskiego kręgu rodziny i przyjaciół. Dlatego wydarzenia traumatyczne, burzące ład świata, stymulują powstawanie opowieści autobiograficznych.

Dlatego też naturalnie obie wojny światowe przyniosły obfitość zapisków autobiograficznych zwykłych ludzi. Casus szczególny stanowi jednak Zagłada - według Alana Milchmana i Alana Rosenberga „wydarzenie przekształcające”, diametralnie zmieniające oblicze ludzkiej historii przez stworzenie nowej „obiektywnie realnej możliwości” zaistnienia „świata śmierci”15. Jerzy Jedlicki zwrócił uwagę

8 A. Farge, op. cit., s. 22.

9 M. Czermińska, Autobiograficzny trójkąt. Świadectwo, wyznanie i wyzwanie, Kraków 2000, s. 14.

10 Narracja jako sposób rozumienia świata, red J. Trzebiński, Gdańsk 2002, s. 8.

11 P. Lejeune, Wariacje na temat pewnego paktu, Kraków 2002, s. 10.

12 J. Leociak, Polscy Żydzi - strategie autobiograficzne, „Kwartalnik Historii Żydów” 2001, nr 4, s. 612-613.

13 M. Czermińska, op. cit., s. 19-21.

14 J. Leociak, op. cit., s. 613.

15 A. Milchman, A. Rosenberg, Eksperymenty w myśleniu o Holocauście. Auschwitz, nowoczesność, filozofia, red. Z. Stefanowska, J. Sławiński, Warszawa 2003, s. 14-15. 
na uderzającą (nawet jak na warunki wojenne) powszechność tworzenia zapisków osobistych $\mathrm{w}$ zmienionej rzeczywistości oraz na ich proweniencję. Pamiętniki i dzienniki (w istocie różne formy pisarstwa, nazywane tak przez swoich autorów) zaczęły pisać dzieci, ludzie prości, słabo wykształceni, nawet ci o bardzo miernych kompetencjach językowych ${ }^{16}$. Zagłada często była jedynym punktem odniesienia ich pisania, w innych warunkach zapewne pozostaliby milczącymi aktorami dziejów. Istnieją wyłącznie jako autorzy relacji o Zagładzie, często pozostają anonimowi. Ich zapiski mają wartość świadectwa, potencjalna wartość artystyczna schodzi na dalszy plan. Zdaniem Jedlickiego tworzenie zapisków świadczyło o poczuciu historycznej ciągłości, ich autorzy bowiem, znajdując się w sytuacji ekstremalnej, wierzyli, że jest to tylko przerwa w normalnym toku dziejów i że równowaga powróci, a wraz z nią sprawiedliwość. Tylko przy takim założeniu możliwe jest przyjęcie strategii świadka. Świadectwo musi być, w normalnych czasach, odczytane.

Autobiograficzne narracje z okresu Zagłady są stopniowo rozwijającymi się zapisami katastrofy. Polega ona na zburzeniu ram bezpiecznego, oswojonego świata codziennej egzystencji, pełnego czynności i gestów znanych, oswojonych, podejmowanych „z przyzwyczajenia”, niewymagających głębszej refleksji, dalej na zerwaniu "naturalnego" biegu rzeczy pozwalającego jednostce realizować swój „normalny" schemat biograficzny ${ }^{17}$. W ten sposób stawały się zapisami nieporządku, sytuacji totalnego kryzysu, kiedy rzeczywistość społeczna przestaje odpowiadać oczekiwaniom, staje się trudna do przyjęcia, gdyż podważa dotychczasową logikę codzienności ${ }^{18}$. Dawały świadectwo całkowitej niepewności, poczucia, że rzeczywistość wymyka się spod kontroli, a co gorsza nie wiadomo, jak ją opisywać. Autorom brakowało gotowych, znanych schematów narracyjnych. Opowieści o I wojnie światowej i ówczesnej niemieckiej okupacji okazały się nieaktualne, nieprzydatne. Tym trudniej było zrozumieć i opowiedzieć własne doświadczenia.

Opowieści o wojnie, lęku, nieszczęściu i cierpieniu są, jak i inne, zapisami zgodnymi ze znanymi w społeczności kodami mówienia o takiej sytuacji ${ }^{19}$. W przypadku Zagłady kodów tych autorom relacji brakowało. Zagłada była doświadczeniem apokalipsy, totalnego zburzenia dotychczasowego porządku świata, a taką sytuację trudno nazwać. Lawrence L. Langer pisał:

po wydarzeniach tak nienormalnych wszystkie nasze definicje normalności wydają się jałowe i niewystarczające, skoro nawet tak podstawowe słowa jak ch a o s nie są w stanie oddać, choćby w przybliżeniu, moralnej i duchowej anarchii tych złowrogich czasów ${ }^{20}$.

16 J. Jedlicki, Dzieje doświadczone i dzieje zaświadczone, [w:] Dzieło literackie jako źródło historyczne, Warszawa 1978, s. 345.

17 P. Berger, T. Luckmann, Społeczne tworzenie rzeczywistości, przeł. J. Niżnik, Warszawa 1983, s. 58.

18 Ł. Rogowski., R. Skrobacki, D. Mroczkowska, Codziennośc w kryzysie, „Kultura i Społeczeństwo” 2010, nr 1, s. 38.

19 A. Farge, op. cit., s. 21.

20 L.L. Langer, Neutralizowanie Holocaustu, „Literatura na Świecie” 2004, nr 1/2, s. 142. 
Paradoksalnie, tym częściej pisano. Philipe Lejeune, analizując dziennik Anny Frank, podkreślał, że to właśnie sytuacja ekstremalna uczyniła z niej pisarkę ${ }^{21}$. Narracje Zagłady są jej świadectwem — zamierzonym, bo taki nakaz pisania formułowali ich autorzy, ale też i niewerbalizowanym, realizowanym w konstrukcji podmiotu. Emmanuel Levinas twierdzi, że literatura Holocaustu przez to, że zakłada obowiązek świadczenia, dokonała zmiany podmiotowości - jest dawaniem świadectwa istnieniu i cierpieniu drugiej osoby ${ }^{22}$. Jest też zapisem świata rozbitego, a jej lektura staje się przede wszystkim lekturą katastrofy, nieporządku²3.

\section{Zapisy nieporządku}

„Lekturę nieporządku” dają teksty bardzo różne — od dzienników i pamiętników powstających „tam i wtedy”, po relacje pisane ex post. Opozycja ta jest podstawową kwestią w piśmiennictwie Holocaustu. Teksty współczesne Zagładzie są artykulacją nowego i radykalnie obcego doświadczenia, stosują strategie oswajania koszmaru, te powojenne zaś oswajają pamięć, zajmują się konstruowaniem autobiograficznej tożsamości ${ }^{24}$. Jeśli chodzi o zapis rzeczywistości, to wobec tekstów powojennych można by czynić zastrzeżenie podstawowe - ich autorzy wiedzieli „co było dalej”, przyjmowali rolę komunikacyjną „wspominającego ocalonego", wedle określenia Jacka Leociaka ${ }^{25}$.

Niezależnie jednak od sytuacji komunikacyjnej, od gatunku piśmiennictwa, jakiemu przynależą, tym, co łączy narracje Zagłady, jest zapis doświadczenia rozpadu świata. „Podejście treściowe” pozwala na zestawianie z sobą tekstów heterogenicznych — właśnie „o ile łączy je wspólnota treści”26.

Propozycja „lektury nieporządku” będzie się opierać na zapiskach autobiograficznych (pamiętnikach, dziennikach) powstających w czasie Zagłady oraz na relacjach wywołanych, spisywanych ex post. Status tekstów nie jest jednorodny. Niektóre miały pewne aspiracje do literackości i naśladowały stylistykę dziennika intymnego, inne były nieporadnymi próbami kronikarskiego opisu rzeczywistości. Klasyfikacja gatunkowa nie jest w tym przypadku tak istotna, słuszna bowiem wydaje się propozycja Leociaka takiej lektury tekstu, „w której jest on przede

${ }^{21}$ P. Lejeune, W jaki sposób Anna Frank napisała na nowo dziennik Anny Frank, „Pamiętnik Literacki” 2002, nr 2, s. 6.

22 D. Głowacka, „Jak echo bez źródła”. Podmiotowość jako dawanie świadectwa a literatura Holocaustu, „Teksty Drugie” 2003, nr 6, s. 50-54.

23 Określenie „lektura nieporządku” wynika z inspiracji rozważaniami Arlette Farge nad wojną (A. Farge, op. cit.). Farge, pisząc „lire le desordre”, miała na myśli lekturę wszelkich źródeł świadczących o zaburzeniach porządku publicznego w okresie wojny. Jako „lekturę nieporządku” będę rozumieć lekturę zapisków oddających poczucie zaburzenia „normalnego” porządku świata.

24 J. Leociak, Tekst wobec Zagłady (o relacjach z getta warszawskiego), Wrocław 1997, s. 25-26.

25 Ibidem, s. 25.

${ }^{26}$ J. Tokarska-Bakir, Obraz osobliwy. Wielkie opowieści, Kraków 2000, s. 35-36. 
wszystkim sposobem ujawniania się autora”, w której liczy się sposób zapisywania wydarzeń ${ }^{27}$.

Relacje wywołane, spisywane już po wojnie, koncentrują się na rekonstrukcji wydarzeń i przeżyć narratorek. Z wyjątkiem relacji Poli Rotszyld, wszystkie zostały opublikowane. Dziennik z getta warszawskiego Mary Berg, tekst „hybrydyczny”, łączący formułę dziennika intymnego i wspomnienia ${ }^{28}$, był pierwszym opublikowanym po angielsku tekstem dokumentującym życie w getcie warszawskim. Jego autorka cieszyła się specjalnym statusem, albowiem jej matka była obywatelką amerykańską. Dzięki temu cała rodzina znalazła się w grupie osób przeznaczonych na wymianę jeńców $\mathrm{z}$ aliantami, po rocznym pobycie $\mathrm{w}$ Vittel dotarła do Nowego Jorku i przeżyła wojnę. Mary Berg po wojnie przeredagowała swoje zapiski. Dzienniczek Basi Rosenberg, pisany w Przeworsku w latach 1938-39 to niewprawne i nieregularne zapiski córki handlarza cukrem. Urywają się bardzo szybko, bo pod koniec września 1939 roku. Ich autorka nie przeżyła wojny. Moja czastka życia Ity Dimant to literacka relacja spisywana po wojnie. Wykorzystałam jeszcze Dziennik Ani Anny Grasberg-Górnej z getta warszawskiego oraz fragmenty pamiętników opublikowane przez M. Grynberga (Pamiętniki z getta warszawskiego. Fragmenty i regesty, Warszawa 1993). Tym, co łączy teksty, jest misja „przekazywania prawdy" - charakterystyczne założenie dla autobiografii, odsuwające na plan dalszy cele "estetyczne"29. Kolejna rzecz to stosunek do historii pojmowanej jako ciąg wydarzeń. Autorki nadają jej duże znaczenie, starają się odtwarzać fakty, niekiedy przytaczają treść obwieszczeń władz okupacyjnych, podają cyfry i daty. To postawa dokumentalisty, świadomego kronikarza dbającego o wierność szczegółom. Własny sposób przeżywania relacjonowanych wydarzeń, własne emocje są dla narratorek „dodatkiem”, jednak z biegiem czasu to one zaczynają dominować w zapiskach. Historia staje się historią przeżywania kolejnych nieszczęść i cierpień.

To, że teksty są dziełem kobiet, a właściwie dziewcząt, jest istotne bynajmniej nie dlatego, że miałoby powodować większą koncentrację na opisach życia codziennego, a potem na uczuciach i emocjach. Męskie opowieści o Zagładzie, podobnie jak kobiece, opisują codzienne „krzątactwo” wokół zaspokojenia podstawowych potrzeb egzystencjalnych (wystarczy wspomnieć Dawida Rubinowicza starannie wyliczającego ceny artykułów spożywczych), dużo miejsca poświęcają stereotypowo „nie-męskim” emocjom - lękowi, przerażeniu, cierpieniu. Chodzi raczej o to, że autorki zapisków na początku wojny wyrażały przekonanie, iż przynależały do grupy tradycyjnie wyłączonej z działań wojennych, chronionej — kobiet i dzieci. Złamanie tej zasady, podobnie jak bezsilność mężczyzn, były dodatkowymi znakami zburzenia naturalnego porządku. Zaprzeczenie kodom porządku płci jest ewidentną oznaką chaosu i nadciągającej apokalipsy.

\footnotetext{
27 J. Leociak, op. cit., s. 27.

28 S. Vice, Children Writing the Holocaust, New York 2004, s. 120.

29 P. Lejeune, Wariacje na temat pewnego paktu: o autobiografii, Kraków 2001, s. 15.
} 


\section{Zapowiedzi katastrofy}

Impulsem pisarskim dla wszystkich autorek stał się najpierw wybuch wojny, potem Zagłada. Mary Berg wcześniej prowadziła przez jakiś czas pamiętnik, ale jak wspominała, czyniła to nieregularnie i w końcu zarzuciła pomysł. W drugim tygodniu września 1939 roku uznała, że to „dobry moment do podsumowania”30. Potem, już w getcie, kilkakrotnie zaznaczała, że pisanie służyć miało dokumentowaniu przeżywanego koszmaru. „Piszę pospiesznie z myślą, że kartki te znajdą się kiedyż w wyzwolonej Warszawie” - deklarowała nieznana autorka fragmentarycznie zachowanego pamiętnika ${ }^{31}$. We wszystkich zapiskach zmieniony, inny czas miał swój dokładnie określony początek. 1 września 1939 roku to „[p]amiętny dzień, od którego zaczęły się nasze nieszczęścia”32. Wojna, mimo że spodziewana, zapowiadana, nie mieściła się w obrazie świata autorek analizowanych narracji. Jej perspektywę odrzucała świadomość obawiająca się zburzenia ram dotychczasowej, bezpiecznej i stabilnej, egzystencji. Basia Rosenberg 1 września notowała: „Wojna. Mówiono ciągle o tem, a jednak nikt nie wierzył, że wybuchnie"33. Mary Berg i Pola Rotszyld, pisząc o opiniach na temat spodziewanego wybuchu wojny w ostatnich dniach sierpnia 1939 roku, także lokowały ją w sferze plotek i alarmistycznych pogłosek, którym nie chciano dawać wiary. A jednak wojna wybuchła i stała się czasem skrajnie odmiennym, rządzącym się innymi prawami, prawami chaosu. Poczucie radykalnej zmiany widać we wszystkich zapiskach. „Aż trudno mi uwierzyć, że zaledwie sześć tygodni temu byłam $\mathrm{z}$ rodziną $\mathrm{w}$ uroczym uzdrowisku, $\mathrm{w}$ Ciechocinku, korzystając $\mathrm{z}$ beztroskich wakacji” ${ }^{34}$ - wspominała Mary Berg. Chaos i groza pierwszych dni września unaoczniały tragiczną cezurę czasową , Jakże inny był przyjazd do Warszawy z letniska każdego roku, a jakże inny - dzisiaj”35. Wybuch wojny stał się realizacją obaw, plotek i pogłosek - tego, co dotąd rozum, a raczej potoczny zdrowy rozsądek, nakazywał lekceważyć w imię komfortu psychicznego.

Wojna, nieszczęście totalne, dotykające całą zbiorowość, do autorek relacji docierała najpierw w skali mikro. Łączyła się z obawą o losy rodziny. Mary Berg martwiła się o wujka walczącego na froncie, a potem przebywającego w niemieckiej niewoli, Pola Rotszyld - o ojca: „Jak sobie wyobrażałam wojnę? Przede wszystkim dławiła nieustanna obawa o to, czy tatusia nie wezmą do wojska"36. Taki lęk mieścił się jeszcze w ramach normalnych wyobrażeń o świecie. Zagrożenie po-

30 M. Berg, Dziennik z getta warszawskiego, Warszawa 1983, s. 13.

31 [Nieznana autorka], Pamiętnik nr 2, [w:] M. Grynberg, Pamiętniki z getta warszawskiego. Fragmenty i regesty, Warszawa 1993, s. 198-199.

32 P. Rotszyld, Wspomnienia [maszynopis], s. 2.

33 Dzienniczek Basi Rosenberg, Przeworsk 1997, s. 56.

34 M. Berg, op. cit., s. 13.

35 P. Rotszyld, op. cit., s. 3.

36 Ibidem, s. 1-2. 
wołaniem mężczyzn do wojska należało do „zwykłego” schematu sytuacji wojny. Podobnie problemy z aprowizacją, zjawisko paskarstwa. Te zjawiska funkcjonowały w świadomości autorek relacji dzięki rodzinnej pamięci poprzedniej wojny. Taka pamięć z jednej strony oferowała apokaliptyczną wizję wroga - ojciec Poli Rotszyld pamiętał Niemców z okresu I wojny światowej jako tych, którzy „gdzie się ukażą, przynoszą ze sobą nędzę i tyfus" ${ }^{37}$. Z drugiej zaś - pozwalała na pewne przewidywania co do przyszłości. Owa świadomość, znajomość konwencji zachowań wojennych, w połączeniu z potoczną wiedzą na temat sytuacji w Niemczech nakazywała ucieczkę z oblężonej Warszawy rodzin policjantów, wojskowych oraz żydowskich mężczyzn. To, „że mogą [Niemcy] coś złego nawet kobietom lub dzieciom zrobić, nie wpadło nikomu na myśl" ${ }^{\prime 3}$. W świadomości powszechnej istniała specjalna kategoria osób podlegających ochronie. Potoczna moralność nakazuje chronić kobiety, dzieci, szlachetnych starców. Złamanie takich potocznych reguł (przede wszystkim w warstwie deklaratywnej, bo w praktyce, jak pokazują studia nad genderowym aspektem przemocy wojennej ${ }^{39}$, naruszała je każda wojna) powoduje wyłom w stabilnej wizji świata, burzy uznany i bezdyskusyjny porządek moralny. Pola Rotszyld kilkakrotnie ze zgrozą podkreślała, że ofiarami szykan okupanta padają także kobiety.

„Normalne”, potoczne wyobrażenia o wojnie, zakładają, że strony walczące stosują się do podstawowych reguł honorowego postępowania. $Z$ drugiej strony, plotki i pogłoski niezwykle ochoczo przypisują przeciwnikowi łamanie owych reguł, stosowanie szczególnie okrutnych, nieczystych chwytów. Zapiski Basi Rosenberg i Mary Berg dokumentują takie opinie. W czasie chaotycznej wędrówki z Łodzi do Warszawy rodzinę Mary ostrzegano przed piciem wody z zatrutej studni. Basia powtarzała oficjalne komunikaty: „Bębniono dziś i przez radio zapowiadano, by nie podnosić z ziemi cukierków, czekolad, ani żadnych innych przedmiotów, gdyż są one zrzucane z samolotów niemieckich i są zatrute" i fantastyczne plotki: „Opowiadano dziś u nas, że jeden znalazł zapalniczkę, zapalił nią papierosa i nagle stał się trupio blady i wyciągnięty. Czy umarl, nie wiem" ${ }^{40}$. Te drugie, nawet jeśli nie były dla niej całkowicie wiarygodne, budowały obraz wroga, jego nikczemnej kondycji moralnej. Basia wyraźnie oburzała się na „nieszlachetny sposób prowadzenia walki”, na to, że wróg (jego demoniczną reprezentacją jest w zapiskach sam Hitler) „chce wytruć dzieci”. Zatrute cukierki i zapalniczki pojawiały się w tekście na podobnych prawach, co informacje o ostrzeliwaniu kolumn uchodźców i bombardowaniu szpitali. Fantastyczne pogłoski i informacje prawdziwe spotykały się na tej samej płaszczyźnie, a to potęgowało wrażenie chaosu.

37 Ibidem, s. 14.

38 Ibidem, s. 5.

39 J. Goldstein, War and Gender: How Gender Shapes the War System and Vice Versa, Cambridge 2001.

40 B. Rosenberg, op. cit., s. 60-61. 
Doświadczeniem traumatycznym, także przez to, że wymykającym się potocznym definicjom wojny, stało się oblężenie Warszawy. I Mary Berg, i Pola Rotszyld opisywały je jako okres, w którym zawieszeniu ulegają normalnie obowiązujące konwencje zachowań. Brak żywności powodował, że można było zjeść nie tylko ostatniego łabędzia z parku Krasińskich, lecz także padłe konie. Obraz wygłodniałych ludzi wycinających kawałki mięsa z jeszcze drgających, konających koni nabierał u obu autorek wydźwięku apokaliptycznego. Tym silniejszego, jeśli weźmie się pod uwagę, że odmowa jedzenia koniny należała do silnego tabu kultury polskiej ${ }^{41}$.

Bombardowania, pożary, konieczność przebywania w prowizorycznych schronach, wreszcie utrata mienia stały się dla obu autorek doświadczeniami granicznymi. Takie poczucie wyraźnie werbalizowała Pola Rotszyld, kiedy celem bombardowania padł jej dom: „A więc już... Przyszło i do nas. Tak jakoś zdawało mi się dotychczas, że u nas nic nie może się stać. Od tej chwili zaś byłam już, nie zupełnie jeszcze, świadomie przygotowana na śmierć" 42 . Groza oblężenia dotknęła jej wtedy osobiście, stała się namacalna, przestała być udziałem „innych”, pojawił się strach.

$\mathrm{U}$ Basi Rosenberg chaos pierwszych tygodni wojny spowodował całkowite zburzenie dotychczasowej egzystencji - łącznie z pojawieniem się wątpliwości co do, dotąd niekwestionowanej, opieki boskiej: „Naprawdę, zaczynam tracić wiarę, ale nie, Bóg nie opuści nas"43. Dominującym uczuciem stał się strach, pojawiło się poczucie braku kontroli nad własnym życiem. Najbliższa przyszłość, dotąd jasna i oczywista, stała się absolutnie nieprzewidywalna: „Co będzie dalej. Moje nerwy są w okropnym stanie” i „Nie wiemy co z nami będzie. Ludzie pocieszają się tylko tem, że to niedługo potrwa. Ale czy my dożyjemy..." Wojna spowodowała utratę najbardziej elementarnego poczucia bezpieczeństwa - pewności, że nadejdzie kolejny dzień: „Nie jesteśmy pewni z życiem ani chwili”44. Dodatkowo w Przeworsku, już we wrześniu, nastąpiło rozbicie dotąd jednego, choć niejednorodnego świata na polski i żydowski. 12 września Basia odnotowała pierwsze ekscesy antyżydowskie - obcinanie bród i pejsów; wkrótce nastąpił przymus pracy. Okrucieństwa ze strony Niemców dopełniało poczucie bycia zdradzonym przez polskich współobywateli: „Ci nasi są jeszcze gorsi od Niemców”45.

Wrzesień 1939 roku jest w przekazach Poli Rotszyld i Mary Berg zaczątkiem nowej rzeczywistości, która okazała się niewyobrażalnym koszmarem,

41 Okupacyjne porady kucharskie, np. w „Nowym Kurierze Warszawskim”, bardzo podkreślały, że należy wyzbyć się przesądów na temat jedzenia koniny - T. Szarota, Okupowanej Warszawy dzień codzienny, Warszawa 1988, s. 244. Koniny przed wojną raczej nie jadano, nie tyle ze względu na ewentualne niedocenianie walorów smakowych, ile na rolę konia w kulturze. Już podręczniki do szkół powszechnych zawierały bałwochwalcze wierszyki na cześć koni, propozycje wypracowań o „zmyślności i szlachetności konia”. Podstawowe aspekty kultury polskiej były niewątpliwie obu autorkom znane i w jakimś stopniu przyswojone.

42 P. Rotszyld, op. cit., s. 8.

43 B. Rosenberg, op. cit., s. 69.

44 Ibidem, s. 59-64.

45 Ibidem, s. 72. 
przerastającym najdrastyczniejsze fantazje: „I jeszcze o tyle, tyle gorzej, nie śniło się nam to podczas najgorszej koszmarnej nocy, nie przeczytałam tego w najfantastyczniejszej, kryminalnej książce"46. Fakt spisywania (Pola Rotszyld) lub redagowania (Mary Berg) relacji ex post pozwalał na „stopniowanie grozy”. Dla Basi Rosenberg pierwszy miesiąc wojny okazał się traumą tak silną, że spowodował absolutną odmowę pisania. Basia zakończyła swój dziennik 24 września 1939 roku. Wówczas to okazało się, że cierpienia nie da się już zapisać, zabrakło języka, w którym można by je było wyrazić. Wcześniej Basia pisała: „Moje ostatnie zapiski to tylko bomby samoloty i alarmy. Oby Bóg dał, by to się już skończyło"47. Zmienionego świata nie dało się już oswoić przez opisywanie go. Brak poczucia elementarnego bezpieczeństwa, wiary we własne przetrwanie nie pozwalał na przyjęcie strategii świadka dokumentującego koszmar dla potomnych. Aby go dokumentować, trzeba go znieść, a to okazało się niemożliwe: „Chwilami ogarnia mnie taka apatia, iż chciałabym umrzeć i koniec. Toż to nie sposób wytrzymać. Teraz już mi wszystko jedno". Pozostało tylko poczucie bezsilności, rozpaczliwa chęć ucieczki: „Chciałabym tylko wyjechać do Ameryki” i decyzja o przerwaniu zapisków.

Sama okupacja nie była na ziemiach polskich sytuacją ani nową, ani nieznaną - starano się do niej przystosować, urządzić na nowo życie - na tyle wygodnie, na ile było to możliwe. Po kapitulacji Warszawy Pola Rotszyld pisała: „Teraz trzeba było powrócić do mniej więcej normalnego życia" ${ }^{48}$. Trzeba było wrócić do szkoły, doświadczenie wojny nie uzasadniało bowiem przerwy w nauce, a poza tym, co całkowicie zgodne z naturalnymi dyspozycjami ludzkiego umysłu, spodziewano się rychłego końca wojny. Należało zatem zachować ciągłość nauki, realizować „normalny” schemat swej biografii.

\section{Porządek Zagłady}

Wkrótce jednak okazało się, że czas okupacji jest czasem diametralnie odbiegającym od wszelkich przewidywań, a tym, co go konstytuowało było nieszczęście i cierpienie. Rok 1940 Pola Rotszyld mogła już wspominać: „okres naszych cierpień był już w toku" 49 . Sygnalizowało go postępujące rozbicie świata. Mary Berg początkowo stosowała cudzysłów, używając określenia „aryjczycy”, dystansowała się wobec tego narzuconego kryterium podziału świata, potem podział na Żydów i Polaków (względnie chrześcijan) przychodził już jej naturalnie. Dla Poli Rotszyld to pęknięcie okazało się niezwykle bolesne; dowodziło zdrady ze strony polskich

\footnotetext{
46 P. Rotszyld, op. cit., s. 14.

47 B. Rosenberg, op. cit., s. 63.

48 P. Rotszyld, op. cit, s. 14.

49 Ibidem, s. 29.
} 
współobywateli, często najbliższych sąsiadów, powodowało kryzys „polskiego elementu" własnej tożsamości:

takie to było niezrozumiałe. Dotychczas żyło się, cierpiało i śmiało razem. Bomba, trafiając, nie pytała „Bist du Jude?” [...] Modliliśmy się i my razem ze wszystkimi dziećmi o zdrowie prezydenta, płakaliśmy po śmierci marszałka Piłsudskiego. Przynosiliśmy oszczędności na fundusz Lopp i T.O.M. i bojkotowaliśmy razem towary niemieckie. A teraz „Jude?”. A Franciszek mówi „Ja" ${ }^{\prime \prime}$.

Powstanie otoczonej murami, wyodrębnionej z tkanki miasta, dzielnicy żydowskiej, unaoczniło fizycznie podział. Tworzenie getta było dokumentowane w zapiskach nie jako akt budowy, ale chaosu. „Nasi ludzie nerwowo biegają ulicami i szeptem przekazują sobie różne wiadomości, jedna bardziej fantastyczna od drugiej. [...] W naszym nieszczęsnym osiedlu brzęczy jak w ulu" ${ }^{2}$. Ciągłe zmiany granic getta, a w związku z tym przymus wielokrotnych przeprowadzek potęgowały poczucie chaosu: „Na podwórzu nastrój okropny, jedni krzyczą, drudzy płaczą, ktoś kogoś oszukał, kręcą się różne ciemne typy, które chcą wykorzystać sytuację"52. Brakowało jasnych reguł: „jeden żandarm przepuszczał, inny zatrzymywał". Powszechnie obawiano się głodu. Dla Poli Rotszyld przeprowadzka do getta (wcześniej mieszkała bowiem na Miedzianej, poza dzielnicą żydowską) wiązała się z pogorszeniem warunków mieszkaniowych, ciasnotą i niewygodą. Rodzina Mary Berg kilkakrotnie zmieniała mieszkanie, zawsze na gorsze.

Nowa rzeczywistość getta przyniosła początkowo względną stabilizację i swoistą satysfakcję z istnienia „żydowskiego państwa”. Mary Berg mogła nawet odnotować: „Doświadczam uczucia dziwnej i nielogicznej satysfakcji, kiedy widzę żydowskiego policjanta na skrzyżowaniu - taki widok był absolutnie nieznany przed wojną" 53 . Pierwszy okres istnienia getta był dla Poli Rotszyld okresem intensywnej nauki, dla Mary - nauki, działalności artystycznej i ożywionych kontaktów towarzyskich. Ich zapiski dokumentują przyzwyczajanie się do nowej sytuacji, budowanie nowej rutyny dnia codziennego.

Szybko jednak zapiski tracą spoistość, narratorki najpierw z niedowierzaniem, potem już tylko przerażeniem zaczęly dokumentować katastrofę. Wszelkie nowe zasady rządzące światem okazywały się bowiem chwilowe, nagle mogły przestać obowiązywać. Czas zaczął płynąć inaczej. Stał się z jednej strony "gęściejszy”, z drugiej zaś w coraz większym stopniu dominowały go wydarzenia i czynności banalne. Zdobywanie żywności, przygotowywanie posiłków, troska o gospodarstwo domowe i pozostawione swojej opiece dzieci wypełniały właściwie całe dnie Poli Rotszyld. Codzienna egzystencja, „krzątactwo”, normalnie organizowana bez

50 Ibidem, s. 16.

51 M. Berg, op. cit., s. 41-42.

52 Z pam. Heleny Gutman-Staszewskiej nr 168, [w:] M. Grynberg, Pamiętniki z getta warszawskiego. Fragmenty i regesty, Warszawa 1993, s. 29-31.

53 M. Berg, op. cit., s. 45. 
głębszej refleksji, przyjmowana z poczuciem oczywistości, stała się teraz przedmiotem skomplikowanych strategii myślowych ${ }^{54}$. Od $1941 \mathrm{r}$. w życiu narratorek na stałe pojawiło się cierpienie fizyczne - głód i choroby. Pola szczegółowo opisywała choroby swoich bliskich, zmaganie się z niedostatkiem żywności. Mary Berg przez długi czas obserwowała nieszczęście, jej własne cierpienie wynikało raczej z empatii niż było uzasadnione sytuacją materialną: „Gdy się już porządnie napatrzę i serce po brzegi wypełni mi smutek, wracam do mojego ciepłego pokoiku, w którym mogę poczuć apetyczny zapach dobrego jedzenia" ${ }^{55}$. Ekstremalny głód nigdy nie stał się jej doświadczeniem. W zamian Mary dokumentowała degradację, jaką głód czynił w otaczającym ją świecie - wspominała ciągle głodną, wychudzoną guwernantkę, młodego człowieka o szlachetnym wyglądzie szukającego pożywienia na śmietniku. Głód stał się podstawową kategorią nowej codzienności. To, że definiował ją brak, niemożność zaspokojenia jednej z podstawowych potrzeb, było dla autorek zapisków dowodem na to, że światem rządzą siły chaosu.

Od 1941 roku w zapiskach coraz częściej, wręcz natarczywie, pojawia się cierpienie. Stało się ono podstawowym czynnikiem organizującym nową rzeczywistość. Było niezasłużone, niezawinione, dotykało także tych, którzy w imię potocznie pojmowanej zasady równowagi, winni być od niego wolni, a więc dzieci. Pola Rotszyld pisała o bracie „Mając dziesięć lat cierpiał już tyle”, o siostrze: „I cóż ona miała $\mathrm{w}$ tym całym swoim życiu. [...] cierpiała razem $\mathrm{z}$ nami nie uskarżając się nigdy"56. Cierpienie dzieci zdecydowanie naruszało poczucie ładu i równowagi - podstawowych elementów potocznej wizji świata. Dopóki zasady te funkcjonowały, świat można było zrozumieć, a życie w nim, nawet jeśli bardzo trudne, było możliwe do zniesienia. Złamanie tych fundamentalnych zasad burzy porządek świata, jest wynikiem działania siły zła ${ }^{57}$. Mimo wszystko, początkowo cierpienie należało do sfery względnej normalności. Związane było z głodem, chorobami - sytuacjami egzystencjalnymi mieszczącymi się w ramach wyobrażeń o świecie i wojnie. Wynikało z braku poczucia bezpieczeństwa, ale jeszcze nie z poczucia grozy. Racjonalne, celowe działania mogły jeszcze cierpienie w jakiś sposób zmniejszyć, bo całkowicie zniwelować się go nie dało. Rodzina Mary Berg mogła wspomagać głodujących uchodźców z Łodzi, a ona sama - swoje koleżanki. „Aprowizacyjna” wyprawa Poli Rotszyld do Zawichostu rzeczywiście przyniosła poprawę bytu całej rodziny.

Wyraźną cezurą stał się dla narratorek rok 1942. Czas realizacji niemieckiej polityki eksterminacyjnej zapisał się dla nich jako maksymalnie zagęszczony czas koszmaru, chaosu, apokalipsy. Przestały obowiązywać najbardziej elementarne prawa wyznaczające porządek świata. Światem zaczął rządzić ślepy

\footnotetext{
54 J. Brach-Czaina, Szczeliny istnienia, Kraków 1999, s. 55-60.

55 Ibidem, s. 51-52.

56 P. Rotszyld, op. cit, s. 53, 83.

57 T. Hołówka, Myślenie potoczne. Heterogeniczność zdrowego rozsądku, Warszawa 1986, s. 142.
} 
Los, pojmowany jako siła fatalna, wyznaczająca kolejne ofiary. Zabrakło jego opatrznościowej konotacji. Nikt i nic nie było w stanie zapewnić ochrony przed złowrogą, ślepą siłą zniszczenia. Cierpienie stało się udziałem wszystkich, bez wyjątku. Nieznana autorka wspominała „akcję” z sierpnia 1942 roku:

12 sierpnia 1942 r. straciłam matkę i ojca. Zabrano ich z jakiejś instytucji gminnej. Nie ja jedna przeżyłam ów ból, nie mnie jedną ogarniała bezsilna rozpacz. Wiem o tym, że cierpieli dookoła wszyscy. Potworny los rozdzielał ludzi najbliższych, a ci, którzy zostawali, skazani jeszcze na parę dni poniewierki i strachu, upadali coraz bardziej na duchu ${ }^{58}$.

Działanie fatalnego losu powodowało poczucie całkowitej utraty kontroli nad własnym życiem. Racjonalne działania nie gwarantowały szans na ocalenie. Ocalenie, podobnie jak śmierć, było kwestią przypadku, ślepego trafu, który na chwilę odsuwał zagrożenie. Dla Poli Rotszyld niezrozumiałe było własne ujście z życiem z blokady, a śmierć najmłodszej siostry - wynikiem przegranej w starciu z fatalnym mechanizmem Zagłady. Zapiski Poli z czasu „wielkiej akcji” dokumentują „znikanie” kolejnych osób, obmyślanie strategii przetrwania, a raczej wymykania się śmierci, absolutną nieracjonalność na świecie.

Relacja Poli Rotszyld od listopada 1942 roku to już tylko zapis czynności pracy przy sprzątaniu mieszkań pomordowanych, przygotowywania posiłków, organizacji kryjówek. Nie ma już żadnych projektów na przyszłość, bo niewerbalizowane poczucie trajektorii nie pozwalało na robienie planów. Pozostało pogodzenie się z losem, zgodne z potoczną zasadą "niech będzie, co ma być «, być może jeszcze wiara w Boga. Skróceniu uległa w zapiskach perspektywa czasowa. Jeśli nie można już było czynić planów, to nawet nadzieja dotyczyła przyszłości najbardziej bliskiej. Nie liczono już na zwycięstwo aliantów, na nadejście armii radzieckiej, tylko na koniec akcji. Nieznana autorka pisała: „Żyłam przecież tak samo, jak wszyscy inni nadzieją, że kiedyś owa potworna »akcja« musi się skończyć" 59 .

Wszechogarniające cierpienie w zapiskach o jesieni 1942 roku traciło swój wymiar fizyczny. Stawało się przede wszystkim cierpieniem związanym z utratą bliskich. Było to cierpienie absolutne, traumatyzujące, śmierci bliskich nie dawało się bowiem wytłumaczyć za pomocą normalnych kategorii. Zwłaszcza, że nie umierali oni, ale „niknęli”, byli „zabierani”, na ogół w najbardziej nieoczekiwanym momencie, niepostrzeżenie, wśród tłumu ludzi, ale bez świadków. Taka śmierć - anonimowa, nagła, jest niemożliwa do zaakceptowania, opłakania, oswojenia przez praktyki religijne. Nie sposób jej zapisać. Dla Anny Grasber-Górnej „[p]roblem teściowej przestał istnieć” i pozornie cyniczny zapis był artykulacją całkowitej bezradności. Dalej autorka pisała: „Boli mnie to bardzo, gdyż wciąż jeszcze liczyłam, na to, że uda mi się ją uratować. Obecnie staram się jak tylko mogę zabezpieczyć Mamę, ale patrząc na rzeczy realnie, niewiele sobie obiecuję.

58 Z pamiętnika nieznanej autorki nr 2, [w:] M. Grynberg, op. cit., s. 117.

59 Ibidem, s. 119. 
[...] Do stracenia nie mamy już nic" ${ }^{30}$. Dla Ity Dimant doświadczeniem cierpienia absolutnego, nieprzemijającego, stało się „zabranie” kuzynki Sary. Nie potrafiła tego wyrazić, język ani znany zasób pojęć nie zapewniały środków do wyartykułowania: „Byłam tylko stężała i w jakimś dziwnym stanie odrętwienia fizycznego. [...] Ból mnie nie zabił. Zranił tylko. A rana ta już nigdy się nie zagoi - dopóki nie znajdę Sarenki”61.

Takie cierpienie jest doświadczeniem kształtującym całe późniejsze życie. Stefania Staszewska, obwiniając się za to, że przeżyła, pisała: „Mamo, to wszystko, co przeżyłam potem, działo się poza mną, ja byłam tylko widzem, i dziś jestem widzem, nie umiem żyć własnym życiem. Tak mamo, ja powinnam wtedy zginąć wraz z Tobą"62. Podobny zapis niewyobrażalnego cierpienia po utracie matki zawiera relacja Poli Rotszyld. Tak wielkie cierpienie burzy podstawy elementarnego porządku świata. Zaprzecza bowiem potocznie pojmowanej zasadzie równowagi - rozumianej jako sprawiedliwy rozdział szczęścia i cierpienia w życiu jednostki. Narracje Zagłady mówią o egzystencji przepełnionej cierpieniem. Do cierpienia sprowadzało się życie brata i siostry Poli Rotszyld, cierpienie było najsilniejszym uczuciem, jakiego sama doświadczała. Przekroczenie możliwej do zniesienia miary cierpienia prowadziło już tylko do pragnienia zakończenia go - chociażby śmiercią. Ukrywająca się po stronie aryjskiej nieznana autorka pisała w lutym 1943 roku: „Myśli o odebraniu życia sobie i dziecku pojawiają się coraz częściej. Nie widzę możliwości przetrwania”63. Jej świat uległ bowiem całkowitej destrukcji.

Narracje osobiste okresu Zagłady są przede wszystkim zapisami cierpienia jako podstawowej relacji jednostki ze światem. Cierpienie, poczucie nieszczęścia stały się podstawowymi kategoriami konstytuującymi opisywaną rzeczywistość. Cierpienie trudno wyrazić słowami. Jest ono „zjawiskiem pozajęzykowym”, wymykającym się znanym kategoriom opisu. Stąd w tak wielu zapiskach powtarzały się stwierdzenia o niemożności opowiedzenia o swoich odczuciach. W percepcji autorek zapisków elementarne zasady, zgodnie z regułami myślenia potocznego rządzące światem, takie jak zasada równowagi, kosmicznej sprawiedliwości, zasada nietykalności pewnej kategorii osób, przestały obowiązywać. Ich miejsce zajęły chaos, przypadek, ślepy, fatalny Los. Świat przestał być miejscem jakiegokolwiek porząaku. Kolejne opisywane wydarzenia dowodziły tylko burzenia kolejnych jego elementów. Lektura dokumentów autobiograficznych okresu Zagłady jest więc „lekturą nieporządku”. A same dokumenty - intencjonalnie tworzonymi świadectwami, wynikającymi z chęci dokumentowania doświadczeń skrajnych, stawiających autorki zapisków wobec rzeczywistości obcej, niezrozumiałej, powstałej

\footnotetext{
60 A. Grasberg-Górna, Dziennik Ani, Ring II, 209/2.

61 I. Dimant, Moja cząstka życia, Warszawa, s. 65-66.

62 Z pamiętnika Stefanii Staszewskiej (Szochur) nr 167, [w:] M. Grynberg, op. cit., s. 137.

63 Z pamiętnika nieznanej autorki nr 2, [w:] M. Grynberg, op. cit., s. 198-199.
} 
na skutek zburzenia wcześniej znanego porządku. Jak uważa Jacek Leociak, właśnie takie doświadczenia, często uznawane za niewyrażalne, „ze szczególną siłą domagają się wypowiedzenia" 64 .

\section{Bibliografia}

Berger P., Luckmann T., Społeczne tworzenie rzeczywistości, przeł. J. Niżnik, Warszawa 1983.

Brach-Czaina J., Szczeliny istnienia, Kraków 1999.

Bruner J., The Narrative Construction of Reality, „Critical Inquiry” 1991, nr 18.

Czermińska M., Autobiograficzny trójkąt. Świadectwo, wyznanie i wyzwanie, Kraków 2000.

Farge A., Des lieux pour l'histoire, Paris 1997.

Giza-Poleszczuk A., Życie jako opowieść: analiza materiałów autobiograficznych w perspektywie socjologii wiedzy, Wrocław 1991.

Głowacka D., „Jak echo bez źródła”. Podmiotowość jako dawanie świadectwa a literatura Holocaustu, „Teksty Drugie” 2003, nr 6.

Goldstein J., War and Gender: How Gender Shapes the War System and Vice Versa, Cambridge 2001.

Hołówka T., Myślenie potoczne. Heterogeniczność zdrowego rozsądku, Warszawa 1986.

Jedlicki J., Dzieje doświadczone i dzieje zaświadczone, [w:] Dzieło literackie jako źródło historyczne, red. Z. Stefanowska, J. Sławiński, Warszawa 1978.

Langer L.L., Neutralizowanie Holocaustu, „Literatura na Świecie” 2004, nr 1/2.

Lejeune P., Wariacje na temat pewnego paktu: o autobiografii, Kraków 2001.

Lejeune P., W jaki sposób Anna Frank napisała na nowo dziennik Anny Frank, „Pamiętnik Literacki” 2002, nr 2.

Leociak J., Polscy Żydzi - strategie autobiograficzne, „Kwartalnik Historii Żydów” 2001, nr 4.

Leociak J., Tekst wobec Zagłady (o relacjach z getta warszawskiego), Wrocław 1997.

Lüdtke A., The History of Everyday Life: Reconstructing Historical Experiences and Ways of Life, Princeton 1995.

Milchman A., Rosenberg A., Eksperymenty w myśleniu o Holocauście. Auschwitz, nowoczesność, filozofia, Warszawa 2003.

Ricoeur P., Histoire et rhétorique, „Diogène” 1994, nr 168.

Rogowski Ł., Skrobacki R., Mroczkowska D., Codzienność w kryzysie, „Kultura i Społeczeństwo” 2010, nr 1.

Szarota T., Okupowanej Warszawy dzień codzienny, Warszawa 1988.

Tokarska-Bakir J., Obraz osobliwy. Wielkie opowieści, Kraków 2000.

Young J.E., Interpreting literary testimony: a preface to rereading holocaust diaries and memoirs, „New Literary History" 18, 1987, nr 2.

Vice S., Children Writing the Holocaust, New York 2004.

64 J. Leociak, op. cit., s. 323. 


\section{Reading what was born out of disorder - a few examples of autobiographical narratives from the period of the Holocaust}

\section{Summary}

The paper is based on the textual analysis of a few chosen autobiographical narratives from the period of the Holocaust in occupied Poland. They were written by teenage girls and young women, mostly in Polish.

"Reading what was born out of disorder" - category formulated by the French historian, Arlette Farge, has been applied as a basis for the analysis. According to Farge's concept, the paper deals with the analysis of the authors attempts to document the disintegration of a well-known world of every-day experiences and their own suffering related to a lack of order in the world around them. 